УДК $327.5: 327.8$

https://doi.org/10.34142/24130060.2019.17.1.02

\title{
СМЕНСЬКИЙ КОНФЛІКТ В РАМКАХ «ХОЛОДНОЇ ВІЙНИ» НА БЛИЗЬКОМУ СХОДІ: ГЕОПОЛІТИЧНИЙ АСПЕКТ
}

\author{
Ель Сафі Баян Максед Салех
}

Харківський національний педагогічний університет імені Г.С. Сковороди

Розглянуто проблему конфлікту в Ємені, як елемента проксі-війни між Саудівською Аравією та Іраном. В результаті чинників різного характеру, звичайне релігійне протистояння двох великих конфесій ісламу, переросло в регіональний конфлікт, в якому замішані інтереси множин держав-лідерів. Наведено хронологію подій переростання конфесійного внутрішнього конфлікту в регіональний. Проаналізовано зацікавленість і таємна роль в конфлікті Саудівської Аравї, США, Ірану, Об'єднаних Арабських Еміратів, а також Ізраїлю. Встановлено, щзо Смен сьогодні став майданчиком для розширення впливу не тільки для Ірану і Саудівської Аравї, а й для інших передових держав за рахунок важливих судноплавних маршрутів. Зроблено спробу вивчення зв'язку між подіями і гравиями в регіоні з використанням теорії ігор.

Ключові слова: проксі-війна, конфлікт, Близький Схід, геополітичні цілі, політичний іслам, ісламські конфесії, холодна війна.

\section{ЙЕМЕНСКИЙ КОНФЛИКТ В РАМКАХ «ХОЛОДНОЙ ВОЙНЫ» НА БЛИЖНЕМ ВОСТОКЕ: ГЕОПОЛИТИЧЕСКИЙ АСПЕКТ}

\section{Ель Сафи Баян Максед Салех}

Рассмотрена проблема конфликта в Йемене, как элемент прокси-войны между Саудовской Аравией и Ираном. В результате факторов различного характера, обычное религиозное противостояние двух крупных конфессий ислама, переросло в региональный конфликт, в котором замешаны интересы множеств государств-лидеров. Приведена хронология событий перерастания конфессионального внутреннего конфликта в региональный. Проанализирована заинтересованность и тайная роль в конфликте Саудовской Аравии, США, Ирана, Объединённых Арабских Эмиратов, а также Израиля. Установлено, что Йемен сегодня стал площадкой для расширения влияния не только для Ирана и Саудовской Аравии, но и для других передовых государств за счет важных судоходных мармрутов. Сделана попытка изучения связи между событиями и игроками в регионе с использованием теории игр.

Ключевые слова: прокси-война, конфликт, Ближний Восток, геополитические цели, политический ислам, исламские конфессии, холодная война.

(C) Е.С. Баян Максед Салех, 2019 


\section{YEMEN CONFLICT WITHIN A COLD WAR FRAMEWORK: GEOPOLITICAL ASPECTS}

\section{Bayan Al Safi}

The problem of conflict in Yemen as an element of the proxy war between Saudi Arabia and Iran is considered. As a result of factors of a different nature, the usual religious confrontation between the two great faiths of Islam, has turned into a regional conflict, in which the interests of the plurality of states-leaders are mixed. The chronology of the events of the emergence of the confessional internal conflict into the regional is given. The interest and secret role played in the conflict between Saudi Arabia, the United States, Iran, the United Arab Emirates, and Israel have been analyzed. It is noted that the intervention of the coalition of states led by Saudi Arabia in the Yemen conflict is a manifestation of ambitions regarding the establishment of the regional leadership of the latter. It has been established that Yemen today has become a platform for expanding influence not only for Iran and Saudi Arabia, but for other advanced states at the expense of important shipping routes.

It is noted that the coast of Yemen is a strategically advantageous area, where the exit from the Gulf of Aden is further in the Red Sea and the Suez Canal. This passage flows through the "gates of tears" (Bab al-Mandebi Strait), and Iran is interested in having an outpost in such an important sea corridor. It was found that the main consequence of the coalition's intervention was to strengthen the "world-recognized" government of Yemen. It is alleged that the escalation of the conflict in Yemen may be related to the so-called "New Middle East" project - the arc of instability in the designated region. An attempt was made to study the connection between events and players in the region using the game theory.

Key words: proxy war, conflict, Middle East, geopolitical goals, political Islam, Islamic denominations, Cold War.

Постановка проблеми. У наші дні проблема збройних конфліктів $є$ найбільш актуальною. Принцип врегулювання різних міждержавних конфліктів військовим шляхом стало нормою. Військові конфлікти виникають в різних районах світу, в них використовується найсучасніше зброю, знищуються цілі міста і велика кількість мирних жителів.

Зовсім недавно на Близькому Сході спалахнув ще один конфлікт як засіб боротьби за регіональне лідерство. Відносини між державами даного регіону напружені вже не перший рік. Ще за часів краху і ослаблення радянського режиму, Близький Схід, що раніше підтримувався СРСР, виявився у вакуумі впливу, який триває до цього дня. У 2003 році США вторглися в Ірак і на той момент слабка система була остаточно зруйнована, що стало причиною виникнення «вогнищ напруженості» в арабських країнах. Арабські країни стали «яблуком розбрату», де такі держави як Іран i 
Саудівська Аравія ділять владу, перебуваючи у вибухонебезпечному стані (Гуськов, 1981).

Аналіз актуальних досліджень. Проблема конфлікту в Смені висвітлена недостатньо в науковій політологічній літературі. Окремі аспекти досліджено в публікаціях М. М. Ба Алаві, М. Наземроая, М. Найтса, а також Д. Жантієва, Г. Косача, А. Крилова та деяких інших.

Метою роботи є комплексне авторське дослідження проблем розвитку даного конфлікту, а також вивчення геополітичних цілей інтеграції різних сторін в проксі-війну між Саудівською Аравією та Іраном.

Виклад основного матеріалу. Протистояння в Ємені висвітлюються мало, тому для початку необхідно стисло навести хронологію подій.

Ємен є великою країною (25 мільйонів жителів), що знаходиться на півдні Аравійського півострова. Той вигляд, в якому країна знаходиться зараз, можна сказати «зшили».

Відносно тимчасового відрізка - це відбулося порівняно недавно, а саме в 1990 році. До цього моменту на даній території існували дві незалежні країни з абсолютно різною долею.

Відмінності беруть коріння ще на етапі формування даних держав, коли Османська імперія панувала на Аравійському півострові. Але південна частина даної території була опорним пунктом Британської імперії, де пролягав важливий торговий маршрут між Азією і Свропою. Північний Ємен проголосив себе Єменським Мутаваккілійскім Королівством в 1918 році, отримавши незалежність від Османської Імперії. У 1962 році після військового перевороту держава стала називатися Сменська Арабська Республіка (Ба Алави, 2014).

Південний Ємен став незалежним набагато пізніше, а саме в 1967 році. У зазначеному році держава отримала незалежність від Британії і пізніше прийняла соціалізм. 
Спільну мову дані території знайшли в 1990 році, держави об'єдналися і проголосили себе Республікою Ємен, але цьому передували нескінченні конфлікти.

Сьогодні в Смені чітка картина політичного ісламу і його руйнівних наслідків, дві великі конфесії ісламу ділять країну навпіл. Перевага в більшій мірі зберігається за сунітами. В їх руках знаходяться легальні демократичні інститути, а значить і переваги політичного впливу. На відміну від другої релігійної групи шиїти відчувають свою безпорадність в рамках діючої політичної системи. Але шиїтські племена більш організовані і боєздатні, тому саме вони є паливом нинішнього конфлікту.

Варто відзначити, що нинішній конфлікт бере свій початок ще в 1962 році. Саме тоді стався переворот в Північному Смені, де відбулося повалення монарха, але племена зейдитів, відмовившись приймати нову владу, почали криваву громадянську війну. Тоді конфлікт зупинили Сгипет, Саудівська Аравія і СРСР, втрутившись і домовившись, але конфлікт лише зупинили, але не закрили.

У 2004 році після арешту проповідника Хусейна аль-Хусі почалося повстання, на цей раз повстанців-шиїтів, які прагнули до відновлення монархії, що існувала Північному Смені до 1962 року, тобто до перевороту (Ба Алави, 2015). Тепер це воєнізоване угрупування отримало назву «Ансар Аллах». Шиїти-зейдити проживають переважно на півночі Ємену i складають третину населення Смену.

Їх опір з новою силою спалахнув під час арабської весни 2011 року, i наступна ескалація сталася вже у 2014 році, коли країну охопили масові демонстрації у відповідь на зростання цін на бензин в два рази у зв'язку із скороченням субсидій на дану область (Noonpost.com, 2014).

Шиїти-зейдити спробували зламати опір силових структур, i їм це вдалося. Вони захопили будівлі державних установ i виставили свої блокпости. Тоді все вирішилося переговорами, влада була змушена піти на це. Угоди стосувалися змін конституції, а саме представництва всіх груп 
населення в інститутах влади. Президент Хаді звернувся до аравійських монархій з проханням. Прохання полягало у введенні до країни контингенту спільних збройних сил. Через загострення ситуації у Смені зібралася навіть Рада безпеки ООН, яка підтвердила легітимність президента Абд Раббо Мансура Хаді (Анбар, 2015).

У відповідь на прохання арабські держави створили коаліцію і розпочали військові операції.

Саудівська Аравія пішла на це, безумовно, заради лідерства. Для країни це шанс показати себе регіональним лідером, це також вагомий привід стати ключовою державою Близького Сходу. Адже, зміцнивши свої позиції, можна здійснювати контроль над арабським світом в цілому.

Почалося протистояння при рівних силах у кожної зі сторін. Саудівська Аравія стягнула до зони конфлікту близько 150 тис. чоловік. Але при цьому, в бойових діях брали участь лише 20 тис. чоловік, що становлять безпосередньо тисячний експедиційний корпус коаліційних сил. Також прихильників президента Хаді налічувалося близько 50 тис. чоловік (Косач та Мелкумян, 2012). Чисельність Ансар Аллах склала приблизно 170-190 тис. чоловік. Армією командував колишній президент Алі Салех, який підтримав опозицію.

Іран, як країна, що перемогла шиїзм, скористалася ситуацією i забезпечила хуситів різної бойовою технікою, в тому числі, ракетами середньої дальності «Буркан-2» і китайськими протикорабельними ракетами C-802 (Knights, 2018).

Слід зазначити, що «провінційний» статус конфлікту, дав наслідки в «геополітичному» плані.

Узбережжя Смену є стратегічно вигідною територією, де $є$ вихід 3 Аденської затоки, далі - в Червоне море і Суецький канал. Даний вихід протікає через «врата сліз» - Баб-ель-Мандебську протоку (Мелкумян, 2017).

Ірану дуже вигідно мати форпост в такому важливому морському коридорі. Громадянська війна в Смені переросла у впізнавану у всьому світі 
проксі-війну між Саудівською Аравією та Іраном. Уряд Смену був нездатний провести реформи, влада не мала впливу в окремих регіонах (в першу чергу шиїтських). Відсутність комунікації між владою і релігійними і політичними меншинами, економічний спад, зростання безробіття, посилення міжрелігійної ворожнечі та регіонального протистояння між Іраном i Саудівською Аравією призвела до загострення протистояння.

Зараз війна в Смені прийняла затяжний характер. Це вже не релігійний, а регіональний конфлікт, де перетинаються інтереси держав-лідерів: Ірану і Саудівської Аравії, і не тільки. В даному випадку необхідно розглянути суперечності між Саудівською Аравією та Іраном, що стали причиною невдачі.

Іран вважається ключовою загрозою саудівської національної безпеки. Незважаючи на загальні релігійні та культурні риси, Саудівська Аравія і Ісламська республіка Іран мають суперечливі політичні погляди. Два режими конкурують за лідерство і вплив в регіоні: Іран являє собою шиїтський полюс, в той час як Ер-Ріяд очолює сунітський полюс в регіоні, і з часом суперечка перетворилась на ідеологічну та політичну битви. Глибокі релігійні та етнічні суперечності мають значення. Режим Тегерана пропонує іншу модель політичного ісламу і виявляє інші погляди на ісламське минуле і майбутнє. Саудівська Аравія дотримується підходу салафітів «традиціоналізм» на Близькому Сході, а Іран дотримується підходу 12-го імама, який обгрунтовує філософію шиїтської думки і містить ідею про те, що колись настане століття справедливості і правди, коли 12-й імам альМахді повернеться як месія. I до тих пір, у шиїтів немає жодного авторитету (Islam4u.com, 2014).

Саудівська Аравія є важливим союзником США, а Іран вважає Америку і імперіалістичний режим своїм головним ворогом.

Така політична розбіжність, викликає занепокоєння в обох країнах через побоювання за те, що політичний баланс буде порушений на користь 
однієї з них. На думку аналітиків, напад Саудівської Аравії показує, що їі побоювання більш актуалізовані, ніж у Ірану.

Однак, відомо, що іранська присутність і вплив в Іраці та Лівані сильніше, але Саудівська Аравія до конкретних дій не вдається. Тут беруть свій початок підозрілі питання, виникає невпевненість, що іранська загроза є мотивом цієї війни.

Між даними державами, так звана проксі-війна, тобто міжнародний конфлікт між країнами на території третьої країни. Щоб конфлікт вважався проксі-війною, повинні існувати прямі, довгострокові відносини між зовнішніми суб'єктами і залученими сторонами.

У такій війні, іноземні держави вважаються ще однією стороною конфлікту, які в свою чергу надають супротивникам ресурсну, політичну i військову підтримку заради досягнення своїх цілей.

В даний конфлікт на сьогоднішній день втрутилося безліч інших країн. Наприклад, в США заявили, що підтримують кампанію проти повстанців, але не беруть участі в ній, і Саудівська Аравія не могла відчувати себе в безпеці і сміливішою без запобіжних заходів і гарантій, наданих їй американським союзником.

Тут необхідно нагадати про проект «Новий Близький Схід», який був публічно представлений в червні 2006 року в Тель-Авіві. Проект полягає у створенні дуги нестабільності, хаосу і насильства, що тягнеться від Лівану, Палестини i Сирії до Іраку, Перської затоки, Смену, Ірану i кордонів гарнізонів НАТО в Афганістані. Тут можна дійти висновку, що проект «Новий Близький Схід» може бути зв'язний з підтримкою США військових дій в Смені як частина виконання проекту (Nazemroaya, 2006).

Ємен сьогодні став майданчиком для розширення впливу не тільки для Ірану і Саудівської Аравії, а й для інших передових держав за рахунок важливих судноплавних маршрутів.

Об'єднані Арабські Емірати, також втрутившись у війну, намагаються зміцнити свої позиції на даній території. При тому, що спочатку коаліція 
була сформована лише 3 метою зупинити наступ повстанців (Малышева, 2010).

Головним наслідком втручання коаліції мало стати зміцнення «всесвітньо визнаного» уряду Смену. Однак нещодавні події показують, що OAE вважають за краще підтримувати альтернативних партнерів сепаратистів «Південної Перехідної Ради» і «залишки» Загального народного конгресу Смену (партія, заснована Алі Абдаллою Салехом).

На думку окремих політичних кіл, ураження Саудівської Аравії в Смені морально неминуче. Туреччина і Пакистан та ще 8 мусульманських країн повинні були брати активну участь у війні проти Смену, як вважав політикум Саудівської Аравії. Але розчарування призвело до співпраці з Ізраїлем та міжнародної критики як країни, яка очолює ісламський світ, взаємодіє із сіоністським режимом у війні проти мусульманської арабської країни.

Втручання Ізраїлю у війну проти Смену більше не є секретом, цей рівень ізраїльсько-саудівських відносин аналізується в ЗМІ багатьох країн. Вважається, що в даному випадку спільним ворогом $є$ Іран. Спочатку домінувала думка, що Ізраїль взаємодіє з режимом Саудитів в рамках участі винищувачів та ізраїльських льотчиків у бойових операціях, а також у межах співпраці з інформаційних справ та безпекової політики (Al-sharq.com, 2018).

Світові ЗМІ також не приховують співпрацю Ізраїлю з Саудівською Аравією в плані обмеження ядерної програми Ірану.

Іншою причиною посилення інтеграції між Ізраїлем і Саудівською Аравією, зокрема у війні з Єменом, є те, що Ер-Ріяд і Тель-Авів, перебуваючи в орбіті Заходу, вважаються його основними партнерами на Близькому Сході. Саудівська Аравія у інтеграції з Заходом стала виконавцем найманої війни на Близькому Сході.

Влада Ізраїлю публічно заявляє, що взаємини Саудівської Аравії та Ізраїлю, криються в тому, що арабські держави регіону, розуміючи близькі зв'язки Ізраїлю і США, вірують в роль Ізраїлю, вважаючи, що можуть розраховувати на Ізраїль в боротьбі з Іраном. Схоже, що Саудівська Аравія 
потребує сильної руки, щоб вирішити проблему нестачі льотчиків, і також в справі постачання розвідувальної інформації, після того, як Туреччина i Пакистан утрималися від участі у війні в Смені.

Але тут постає важливе питання про мету Ізраїлю.

Напруженість у відносинах між Ізраїлем і країнами Близького Сходу носить агресивний характер, і тут необхідно було «змоделювати» стратегічну гру, щоб повністю змінити ситуацію.

Одне $з$ наболілих питань Ізраїлю стосується того, що країна на даний час не визнається ісламськими державами в якості законного режиму. Звичайно, Ізраїль підтримує офіційні і неофіційні відносини 3 деякими ісламськими державами, але більшість ісламських і арабських країн не мають послів на окупованій території, не підтримують офіційні зв'язки з Ізраїлем.

Навіть до 2008 року Ізраїль мав офіційний торговий офіс в Катарі. При цьому в деяких часових періодах Саудівська Аравія підтримувала палестинський народ і примушувала уряд Катару закрити торговельний офіс в Досі. Але офіс продовжував функціонувати - Катар відмовлявся від закриття, поки Ізраїль знову не напав на сектор Газа.

Тепер Ізраїль намагається узаконити стосунки із Саудівською Аравією, використовуючи співпрацю у війні з Сменом. Таким чином, Ізраїль 3 упевненістю може очистити себе від різних претензій, таких як злочинний режим і режим, що вбиває дітей, у зв’язку $з$ тим, що величезну кількість палестинських дітей під час нападу Ізраїлю на сектор Газа було поранено і вбито. Сьогодні Саудівська Аравія, нападаючи на Ємен, вбиває дітей, хоча і вважається лідером ісламського і арабського світу. Отже, Саудівська Аравія, своїми руками порушувала мусульманські принципи, зруйнувавши свою репутацію, і спростувавши твердження, що дітей вбиває тільки Ізраїль. Ще одним варіантом співпраці Ізраїлю з Саудівською Аравією можна вважати цілі Ізраїлю щодо контролю над Червоним морем, в рамках плану зі створення Великого Ізраїлю на Близькому Сході. Баб-ель-Мандебська протока має велике військове значення і важливість для безпеки та була 
закрита для Ізраїлю під час війни 1973 р. Після вересневої терористичної атаки 2001 року, США працювали над забезпеченням безпеки в протоці перед обличчям Аль-Каїди і піратів в регіоні (Al-sharq.com, 2018).

Стратегічною метою, яка потребує політичної грі, тут є все та ж Бабель-Мандебська протока. Цей водний шлях - дуже важлива і чутлива тема для Ізраїлю, мова йде про єдиний маршруті з Ізраїлю в Азію.

Хоч і операцію Саудівської Аравії в Ємені називають дещо успішною, результат все-таки є. Це недопущення встановлення контролю Ірану над протокою, що розділяє Смен і Джібуті і з'єднує Червоне море з Аденською затокою (Косач та Мелкумян, 2012).

Також Сауд вдалося залучити в орбіту свого впливу приморські країни - Судан, Еритрею i Джібуті, i не допустити поширення на них зони іранського контролю (Францман, 2018).

Так, саудівська коаліція, до складу якої входить і Єгипет, контролює практично все Червоне море, включаючи Баб ель-Мандеб і Суецький канал.

Висновки і перспективи подальших досліджень. Таким чином, єменський конфлікт став багатостороннім за участі в ньому зовнішніх сил. Зовнішнім учасником конфлікту є, перш за все, Саудівська Аравія, яка очолила міжнародну коаліцію, спостерігається також посилення впливу США і Об'єднаних Арабських Еміратів.

Існує також зацікавленість Ізраїлю в даній війні, незалежно від переслідуваних цілей. Безсумнівно, результат взаємин Ізраїлю і Саудівської Аравії в короткостроковій і довгостроковій перспективі поки що на користь Ізраїлю, а не Саудівської Аравії.

Найбільш ймовірний аналіз подій пов'язує Єменський конфлікт зі створенням Великого Ізраїлю, i показує, що війна $\epsilon$ частиною серії руйнування i перекроювання карти Близького Сходу, яка почалася в Палестині і поширилася на Ірак, Ліван і Сирію. Всі зовнішні сторони, які перетворили внутрішній конфлікт Ємену в руйнівну війну, $\epsilon$ лише учасниками довгострокового стратегічного плану за правилами теорії ігор, 
для нарощування присутності і досягнення різних цілей, таких як проект «Новий Близький Схід» і створення Великого Ізраїлю.

\section{ЛІТЕРАТУРА}

1. Анбар, М., 2015. Текст сообщения «Хади» с требованием к странам Персидского залива вмешаться военным в Йемен. [online] (Последнее обновление 26 марта 2015) Доступно: https://www.youm7.com/story/2015/3/26 / مصطفعنبر/20 / مصرسالة "هادى"

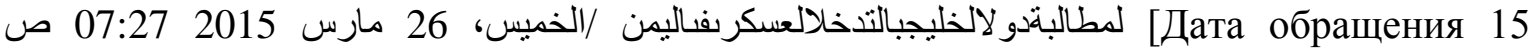
январь 2019].

2. Ба Алави, М.М., 2014. После йеменской революции: разделение страны или федеративное государство. Вестник Днепропетровского университета. 24 (2), 22, с. 137-141.

3. Ба Алави, М.М., 2015. Южное движение и призыв к независимости от Северного Йемена. Евразийский Союз Учёных. 11, с. 81-84.

4. Гуськов, А.С., 1981. Демократический Йемен: Прогрессивная эволюция революционной демократии. Вопросы истории, 1, с. 51-62.

5. Косач, Г.Г. та Мелкумян, Е.С., 2012. Саудовская внешняя политика: к вопросу о национальной интерпретации курса страны. Сборник «Ближний восток $u$ современность», 16. с. 67-114.

6. Малышева, Д.Б., 2010. Йемен как новая горячая точка. Север-Юг-Россия, с. 108-112

7. Мелкумян, Е.С., 2017. Отношение арабских государств Персидского залива к Ирану: новые тенденции. Сборник «Ближний восток и современность», 14. с. 202-210.

8. Францман С., 2018. Дипломатия мира Персидского залива в Африке. [online]

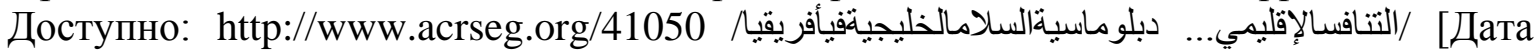
обращения 15 январь 2019]

9. Al-sharq.com, 2018. Саудовская Аравия и Израиль, высокопоставленное разведывательное сотрудничество. [online] (Последнее обновление 5 январь 2018) Доступно:

https://www.alsharq.com/article/05/01/2018 السعوديةو إسر ائيل..تعاوناستخبار اتبعاليالمستوى/ الجمعة 05-2018-01 الساعة ص 2:00 [Дата обращения 15 январь 2019].

10. Islam4u.com, 2019. Doctrine-циить-в-Имам Махди-Алишаа. [online] Доступно:

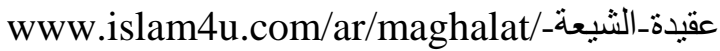
في-الإمام_المهدي-عجُّل_اللهـفرَجَها [Дата обращения 15 январь 2019]

11. Knights, M., 2018. The Houthi war machine: from Guerrilla war to state capture. Combating terrorism center, [online] 11(8), pp. 15-23. Доступно: https://ctc.usma.edu/houthi-war-machine-guerrilla-war-state-capture [Accessed 15 January 2019]

12. Nazemroaya, M., 2017. Plans for Redrawing the Middle East: The Project for a "New Middle East”. [online] (Last updated 18 November 2006) Доступно: https://www.globalresearch.ca/plans-for-redrawing-the-middle-east-the-project-for-a-newmiddle-east/3882 [Accessed 15 January 2019]

13. Noonpost.com, 2014. Эскалачия Хуси́тов, демонстраџии неприятия и ограниченные возможности правительства Йемена. [online] (Последнее обновление 25 августа 2014) Доступно: https://www.noonpost.com/content/3529/ [Дата обращения 15 Январь 2019].

14. Voltairenet. org, 2016. Poland: Israel reveals its military hand in Yemen. [online] Available at: https://www.voltairenet.org/article205207.html [Accessed 15 January 2019]. 


\section{Інформація про автора}

Ель Сафі Баян Максед Салех - аспірантка кафедри політології, соціології і культурології Харківського національного педагогічного університету імені Г.С. Сковороди; e-mail: bayanalsafi@gmail.com; ORCID: https://orcid.org/0000-0001-94400838.

Стаття надійшла до редакції: 21.01.2019 р. $\quad$ Прийнята до друку: 04.02. 2019 р. 